\title{
The Local Culture Values of "Perdikan Cahyana" as a Source of Instructional Material for Elementary Students
}

\author{
Rani Darojah*; Retno Winarni; Tri Murwaningsih \\ Graduate Program, Sebelas Maret University, Indonesia \\ Email: ranidarojah@yahoo.com
}

http://dx.doi.org/10.18415/ijmmu.v5i2.124

\begin{abstract}
The objective of this study was to obtain an innovative instructional material based on local culture of Perdikan Cahyana area to promote students' competences in appreciating fiction stories. The material was developed based on the fiction aspects to meet the requirement of curriculum subject for the fifth-grade students in elementary school and followed by the need analysis results. The material was designed in printed form and it was standardized to meet good quality learning material for elementary student purposes. The results showed that the developed fiction material was categorized as very good. The material was effective to use and be able to motivate the students to appreciate fiction stories. The developed material facilitated the students to involve in the learning process actively which made the learning move from teacher center to student center learning. The significance value was $0.000<0.05$. Therefore, it can be concluded that there was a positive improvement and significant value of learning outcomes of the fiction stories appreciation after the use of developed instructional material.
\end{abstract}

Keywords: Fiction material; Perdikan cahyana; Local culture

\section{Introduction}

Literary learning for the fifth grade students which is suitable with the curriculum is focused on fiction appreciation. According to Aminuddin (2014: 66) fiction is a story which is presented by the act of certain character, setting, and the stages of stories based on the author's imagination to establish a story. In line with Amminudin definition, Nurgiyantoro (2013: 30) also states that fiction is a fictitious story which has characters, plot and structures as a result of author's imagination in a variety of prose. Since fiction is a result of author's imagination, fiction is interesting to read and be able to pleasure the readers' mind and soul. Beside for pleasure, fiction also give some benefits for the readers especially for the student which is closed to reading activity during the learning. As a result of Kidd \& Castano study (2013), they suggest that reading fiction can promote students' social skills complexly and critically. In accordance with those benefit, the availability of fiction story as a reading material for students is very important to help the students to achieve the learning goal of fiction appreciation. Further, Yaumi (2012: 245) states that one of factors which support the success of learning is the availability of an instructional material. Therefore, the availability of instructional material of fiction story will be a challenge for the teachers during the learning activities. 
The next challenge which is faced by the teacher is how to choose instructional materials that can facilitate students in achieving the learning objectives of fiction appreciation. Susanti (2015: 145-146) argues that in the selection of literary learning materials, one of aspects that must be considered is the cultural background of students. It is important because children usually will be easily interested in a literary work which is closed to the background of their life. Further, Nurgiyantoro (2013: 7), states that the material which is closed to the child's life or depart from the child's lens is the basic capital for the child in understanding the text to gain an understanding of the world and life. Therefore, students' background can be a consideration for the teachers in selecting the best material for their students.

Local wisdom-based education has become a hot topic in an education field recently. It is mentioned in a Government Regulation Number 17 in a year of 2010 and in a verse of 34, which mention that "local wisdom-based education is an education which is held after fulfilling the Standard of National Education and it is promoted as an advantage or as a competitive prospect of certain area". Further it is also stated in a Strategic Planning of Educational Ministry in the years of 2010-2014, which state that, "education should foster an understanding to the importance of sustainability and ecosystem balance, especially an understanding to the humans as a part of the ecosystem". Education has a main role to provide an understanding to the social values and natural responsibility to give an illustration for the students as a part of a social system which must synergies with other human beings and a part of the natural system that must synergies with nature and its contents.

Local wisdom contains many local ideas like wise, full of wisdom, good value, peaceful and which is followed by the society, and it is formed as a product of past culture which is deserved as a way of life (Panjaitan, et al., 2014: 115). According to Mua'rifah (2017) local culture is very rich with its local wisdom value and has a common principle which is suitable with the religion and culture universally. The local wisdom contents in an instructional material of fiction stories are expected to help the students in understanding the contents of the story easily which will promote the students' ability to appreciate the fiction story. But in fact, there were still problems in learning fiction story. Based on the results of observations which were conducted to the fifth grade students and the interview results which was conducted to the teachers of elementary school in Perdikan Cahyana area, the writer got information about the availability and utilization of instructional materials of fiction stories which were still very limited. Further, the interviews results showed that local wisdom of Perdikan Cahyana as a content of the instructional material of fiction story was still not seen yet. Therefore, the students got difficult to understand the contents of fiction stories which were provided by the teacher. Finaly, this condition affected the students' competence in appreciating the fiction stories. Furthermore, based on the analysis results to the instructional materials which were commonly used by the teacher and the students, especially the material of fiction stories were still far from interesting. It was because the material was printed with blurry paper and the small font size which made the students difficult to read. Beside, the fiction stories which were presented were not from the students' area, so that students got difficulty in developing their ideas in appreciating the fiction stories.

Teachers believe that integrating local wisdom in an instructional material is able to help to solve the problem recently which is related to global issue. Students need to give an understanding of the local wisdom which is expected as a filter, a self formation, and a guidance of the life. Sularso (2016), finds that the effort to dig, to plant, and to sow the potential of local wisdom is an attempt to return to the value of the repertoire of local wisdom as an effort to build the identity and character of cultural-based learners. Perdikan Cahyana has a lot of local wisdom which can be developed as a source of innovation in the development of instructional materials of fiction stories, namely: (1) Weweh tradition. It is a form of charity attitude of Perdikan Cahyana society which is implemented by giving some food to the new guests; (2) The balance concept of the life. Perdikan Cahyana society highly upholds the balance of society life which is marked by a speech "yen kowe nrima mangan wedhi krikil, ora usah lunga ing wengkonku". It is advice for the society not to enrich themselves excessively to avoid the social gap at the 
time. Beside, the society are expected to maintain a natural balance in its area. Perdikan Cahyana society are not allowed to explore the natural wealth excessively; (3) religious values. The form of local wisdom that is manifested in the religious life of the society in Perdikan Cahyana is a ritual "slametan" and "ziarah". It is a series of activities which is started by ziaroh to the graveyard of Sheikh Jambu Karang at Ardi Lawet by walking as far as $6 \mathrm{~km}$ and it is closed with "slametan" as a form of gratitude towards all the blessings given by God Almighty. "Ziaroh" is a form of respect to the ancestors who have given a main contribution to the Islamic development in Perdikan Cahyana area and have inherited many kindnesses values such as patience, togetherness, loving others, and gratitude towards all creation of Allah SWT.

The objective of this research in general is to produce an instructional material based on local wisdom of Perdikan Cahyana area to improve students' competence in appreciating fiction stories. While, the specific objectives of this study are: (1) to describe the need of instructional materials of fiction stories based on local wisdom; (2) to develop the instructional materials of fiction stories based on local wisdom of Perdikan Cahyana; (3) to examine the effectiveness of the use of instructional materials of fiction stories based on local wisdom of Perdikan Cahyana.

\section{Methodology}

This research was conducted to the fifth-grade students of elementary school in Perdikan Cahyana. This research uses research and development method (Research and Development) Borg and Gall (1983). The data obtained in this study are qualitative and quantitative data. Qualitative data are obtained from the need analysis results of the instructional materials of fiction stories and the implementation of experimental test of fiction stories based on local wisdom of Perdikan Cahyana. While the quantitative data are obtained from the validation of the experts, the questionnaire responses from the students and teachers to the developed material, and the test results of fiction stories appreciation which was given to students at the experiment phase. The result of the test was analyzed using Paired Sample TTest. In this research the writer used statistic program of SPSS 24.

\section{Results and Discussion}

The procedures of instructional material development in this research consists of 3 stages, among namely: conducting needs analysis which is related to the developed instructional material, designing and composing the instructional materials of fiction stories based on local wisdom of Perdikan Cahyana, and conducting the experimental study to examine the effectiveness of the developed instructional material.

\section{Need Analysis}

Fatima Dar (2012) in an article entitled "Textbook Materials and Their Successful Application in the Classroom: Implications for Language Development" explains that the role of instructional materials are very important for the success of learning. Therefore, the development of instructional materials must be suitable with the needs of teacher, students, and also curricula which are implemented in schools. Needs analysis is conducted to obtain the data and supporting information in the development of instructional materials to fit the needs of users of teaching materials.

Based on the needs analysis results, the availability of instructional materials of fiction stories is still very limited. It makes teachers difficult to provide a creative and innovative instructional material. Based on the analysis results of instructional materials which are commonly used by teachers, it is known 
that the material is not suitable with the needs of students. Therefore, it will make students less motivate to read. This condition was proved by the results of observations which was conducted by the writer during the learning process by using the previous teaching materials. Sometimes, students appeared less enthusiastic and many of them find difficulties in appreciating the fiction stories. Based on interviews with students, they got difficulties in appreciating the fiction story because it was less interesting material and the stories which were presented in the material were not in accordance with the local culture of the students' area.

Based on the findings of the needs analysis, teachers and students need interesting instructional materials which present the fiction stories based on the local culture of the students. The development of instructional materials must be suitable with the needs of users of instructional materials and the criteria of eligibility of teaching materials in order to motivate students to learn and improve their competencies in appreciating the fiction stories.

\section{Design and Development}

The development of instructional materials in this research consists of 2 books namely teacher book and student book. Student book is often referred to as textbooks used as learning resources. To facilitate the teacher in carrying out the lesson, the teacher book is prepared as a guide book for the teacher.

In designing the instructional materials in this study, the writer conducted the following steps: (1) analyze the needs of instructional materials; (2) analyze curriculum which is related to standard competence and basic competence; (3) create a competency map that must be mastered by students; (4) collect the material; (5) determine the values of local wisdom to be integrated in instructional materials; (6) determine the instructional material design; (7) make learning instructions; (8) create tasks and evaluation.

Nunan (1995: 211), states that language learning materials should be chosen based on the social, cultural, linguistic and life context of the students. Learning should be useful and beneficial for the students and their environment. To create learning context which is related to students background, Faridi (2008:5) suggest to present the theme that is suitable with the students' environment and give benefit for them. Therefore, to create a learning context for students, the development of fiction material should present the theme of local wisdom of Perdikan Cahyana which is closed to the students and useful in internalizing the values of local wisdom.

Local wisdom is a characteristic or a marker of a certain society which is inherited by the ancestors and it is used as a guide in interacting with humans, nature and God (Geertz., 1973; Utari, Dedeng, \& Akbar., 2016; Suhartini., 2009). To interact with the human (social), in Perdikan Cahyana there is a local wisdom which is manifested in a speech form "yen kowe nrima mangan wedhi krikil, ora lunga-lunga ing wengkonku". It is an advice for the society not to enrich themselves excessively to avoid social gaps. Further, there is also "weweh tradition" which is a form of public disclosure attitude of the society which is embodied by giving some food to their new guests. Of course, these values are very important to be understood by the students to live in society later. In the context of classroom learning, these values can develop cooperative attitudes in a positive sense rather than a growing competitive attitude which often arise in conventional learning.

Soetomo (2012: 128) explains that local wisdom can serve to adjust and maintain the harmony of physical environment with natural environment. In related to the nature, there is a positive value of local wisdom in Perdikan Cahyana which must be appreciated. It was a prohibition of tobacco planting in that 
area at that time. Actually, it is not a form of antipathy to a particular plant but that prohibition must be interpreted as a form of "pepeling" (reminder) for the society to be wise in utilizing the nature in order to maintain the of balance of nature. This reminder is stated because the high economic value of tobacco plant cause people to neglect and act excessively in exploiting the nature. Therefore, the local wisdom of maintaining the balance of nature needs to be understood by students.

Suhartini (2009:1) explains that local wisdom is also related to the religious values of life. In this case the form of local wisdom embodied in the religious life of Perdikan Cahyana society is the existence of "slametan" and "ziaroh" ritual which is a form of respect for their ancestors who have taken important role in the development of Islamic religion in Perdikan Cahyana area. Further, it is also a form of appreciated to them who have inherited a positive value that must be internalized in society like patience, togetherness, loving others, and gratitude towards all creation of Allah SWT.

The prototype of developed instructional material refer to the feasibility criteria of instructional materials such as: the content feasibility, the language feasibility, the graphic feasibility and presentation. As it is stated in the department of national education (2008) which mentions that the instructional materials should be assessed from several aspects: (1) the feasibility of content, (2) language and readability; (3) presentation; and (4) graphics which are equipped with syllabus and lesson plan. Prototype of this developed material has validated by experts by giving a mark scale from 1-5. The results of expert validation were analyzed based on the thus category: (1) $X>4.2$ is very good; (2) $3.4<X \leq 4.2$ good; (3) $2.6<X \leq 3.40$ is sufficient; (4) $1.8<X \leq 3.40$ is less good; (5) $X \leq 1.8$ is not good (Widyaningsih, 2015: 73). The results of Expert validation judgment on instructional material of fiction story based on local wisdom of Perdikan Cahyana can be seen in Table 1:

Table 1 The experts validation for teaching material

\begin{tabular}{llcc}
\hline \multirow{2}{*}{ No. } & The teaching mateial & \multicolumn{2}{c}{ The validation of expert's judgment } \\
\cline { 3 - 4 } & & Average Score & Feasibility \\
\hline 1. & Contents & 4,29 & Very Good \\
2. & Language & 4,18 & Good \\
3. & Presentation & 4,00 & Good \\
4. & Graphic & 4,31 & Very Good \\
5. & Syllabus & 4,05 & Good \\
6. & Lesson Plan & 4,27 & Very Good \\
\hline & Average & 4,18 & Good \\
\hline
\end{tabular}

Source: the average of experts validation for teaching material

Based on Table 1, it is known that the teaching materials of fiction stories based on local wisdom of Perdikan Cahyana get an average score of 4.18 with a description of "good". 

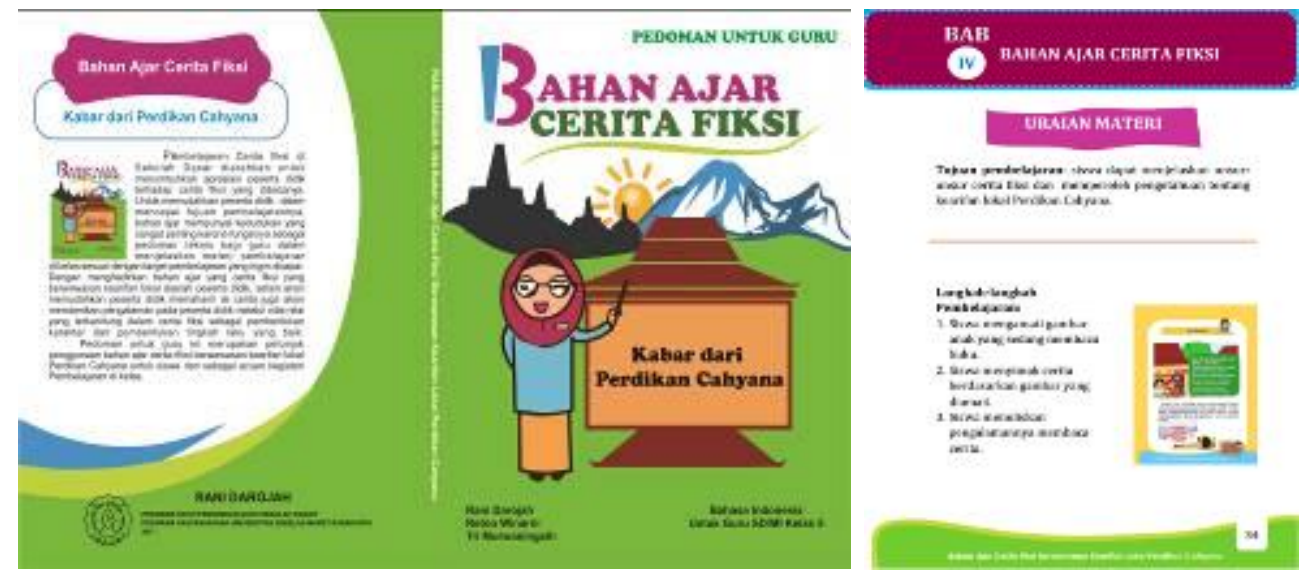

Fig. 1 Teaching material

Based on Table 2, it is known that the developed learning materials of fiction stories get an average score of 4.25 with a description of "very good".

Table 2 The experts validation for learning material

\begin{tabular}{llcc}
\hline & & \multicolumn{2}{c}{ The Validation of Expert's Jugdment } \\
\cline { 3 - 4 } No. & Learning Material & Average Scores & Feasibility \\
\cline { 3 - 4 } & & 4,10 & Good \\
\hline 1. & Contents & 4,00 & Good \\
2. & Language & 4,43 & Very good \\
3. & Presentation & 4,47 & Very good \\
4. & Graphics & 4,25 & Very good \\
\hline
\end{tabular}

Source: the average of experts validation for learning material 


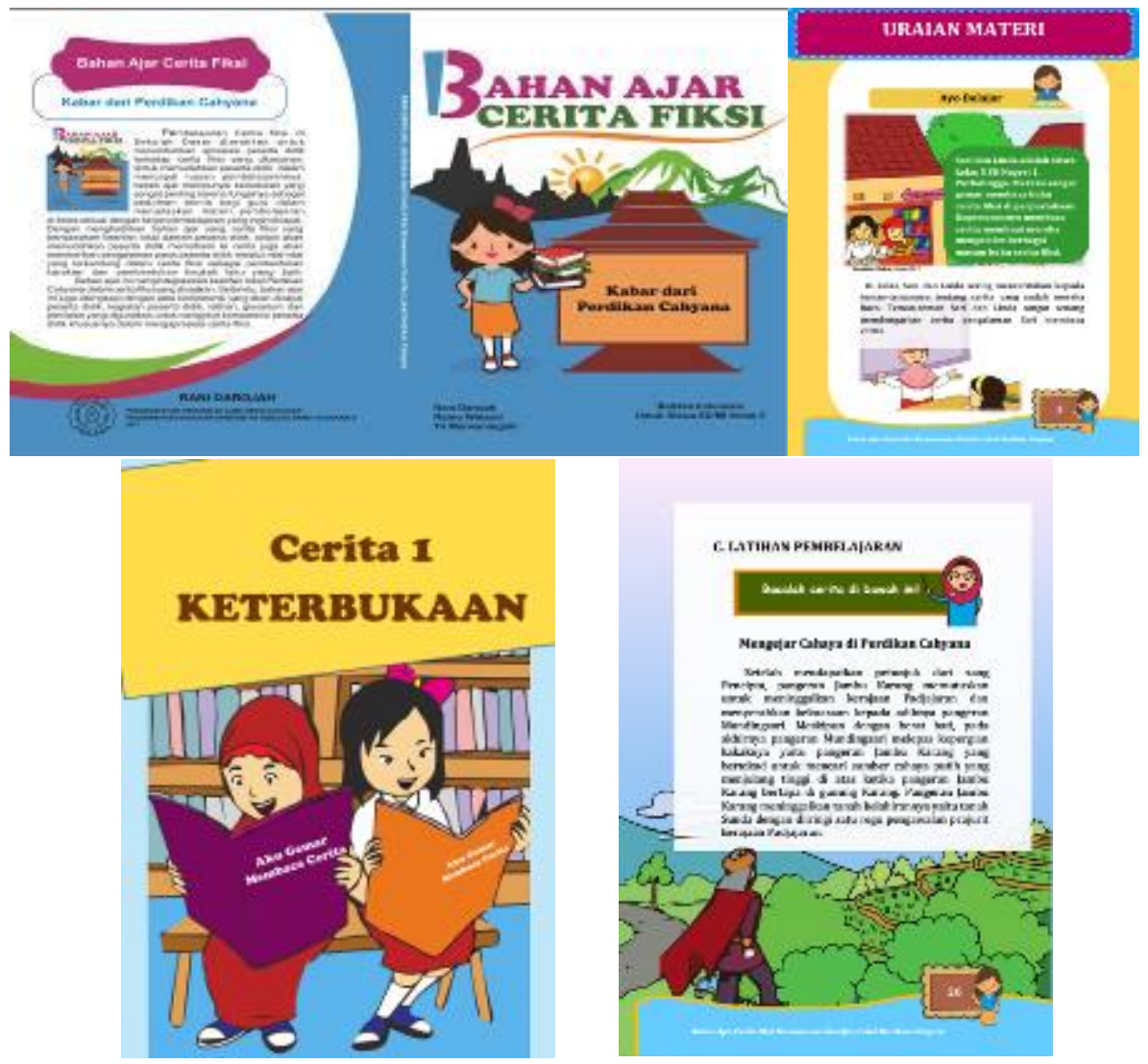

Fig. 2 Learning material

\section{Experiment}

The experiments were conducted in two primary schools in Perdikan Cahyana area. Those primary school are SD N 1 Tajug and SD N 2 Makam. Before conducting paired sample t-test analysis, it is necessary to test the normality of data first. The writer used shapiro-wilk test technique to test the normality of data by using SPSS 24 with the provision if the significance value is greater than $\alpha=0.05$, the hypothesis (H0) is accepted, it means that the sample is from a normally distributed population. The results of normality test data are as follows:

Table 3 The result of normality pre-test and post-test

\begin{tabular}{|c|c|c|c|c|c|c|c|}
\hline School & Class & Categories & Average & $\mathrm{N}$ & Sig. & A & Description \\
\hline & & Pre-test & 71,63 & 22 & 0,280 & 0.05 & Normal \\
\hline & & Post-test & 83,45 & 22 & 0,133 & 0.05 & Normal \\
\hline & & Pre-test & 71,83 & 22 & 0,105 & 0.05 & Normal \\
\hline & & Post-test & 84,18 & 22 & 0,098 & 0.05 & Normal \\
\hline
\end{tabular}

Source: The average scores of students' pre-test and post-test 
The normality test of data from SD N 1 Tajug shows that the significance is 0,280 for pre-test and 0,133 for post-test. These results indicate that the significance is greater than 0.05 . Therefore, $H_{0}$ is received and it can be concluded that the distribution of data is normal. Further, the normality test of data from SD N 2 Makam shows that the significance is 0,105 for pre-test and 0,098 for post-test. These results indicate that the significance is greater than 0.05 . Therefore, $H_{0}$ is received and it also can be concluded that the distribution of data is normal. After the normality test has been fulfilled, the paired sample t-test can be analyzed. The results of paired sample t-test can be seen in Table 4:

Table 4 The results of paired sample t-test

\begin{tabular}{|c|c|c|c|c|c|c|}
\hline Schools & Class & Categories & $\mathrm{N}$ & $\mathrm{T}$ & Df & Sig. (2-tailed) \\
\hline & & Pre-test & 22 & & & \\
\hline & & Post-test & 22 & & & \\
\hline & & Pre-test & 22 & & & \\
\hline & & Post-test & 22 & & & \\
\hline
\end{tabular}

Source: the analysis results using SPSS 24

Based on the output results of Table 4, it can be seen that the significance value is $0.000<0.05$. It means that $H_{0}$ is rejected. Therefore, it can be concluded that there is a positive improvement and significant value of learning outcomes of the fiction stories appreciation after the students were given the fiction material which figure the local wisdom of Perdikan Cahyana.

The developed instructional materials is able to improve student learning outcomes in appreciating fiction. As Richard says (Iswanto., 2015: 224) which states that instructional materials are a key component that essentially provides input, practice, language and means of achieving learning objectives according to the curriculum which is mandated. Furthermore, Richard states that the learning process will be succesful if it is appropriate with the needs and objectives of learning.

Janit, Hammock \& Richrdson (2011: 3) state that the readers perceive similarities between themselves and story characters with respect to age, life stage, social goals, and / or personal goals. Meaning that, when the reader finds a similarity between himself and the existing in the text then the reader will be easier in understanding the contents of the story, plot, goals both personally and socially.

\section{Conclusion}

The results showed that in developing the instructional materials should be appropriate with the needs of students and teachers, the environment around the students, the criteria of a good instructional materials and curriculum which is used in schools. The developed instructional materials based on local wisdom Perdikan Cahyana for the fifth grade students meet the criteria of eligibility and effective learning materials in improving learning outcomes that is fiction stories appreciation. Students get better score in appreciating fiction stories after they are given the developed instructional material for appreciating fiction stories. 


\section{Acknowledgement}

I would like to give a respectful appreciate for all head masters, teachers, and students of both SD N 2 Makam and SD N 1 Tajug, which have given an opportunity for the writer to conduct an experiment in related to the developed instructional material. In addition, the writer also give many thanks to Mr. Wirayudha and Mr. Achmad Sucipto as the representative of Perdikan Cahyana society who have given information and help the writer in exploring the local wisdom value of Perdikan Cahyana.

\section{References}

Aminuddin. (2014). Pengantar Apresiasi Karya Sastra. Bandung: Sinar Baru Algensindo.

Borg, W. R dan Gall, M. D. (1983). Educational Research and Instroduction. Newyork: Longman.

Dar, Fatima.(2012). Textbook Materials and Their Successful Application in the Classroom: Implications for Language Development. Pakistan: School of Education Beaconhousse National University.

Depdiknas. (2008). Panduan Pengembangan .Materi Pembelajaran dan Standar Sarana dan Prasarana. Jakarta: BP Mitra Usaha Indonesia.

Faridi, Abdurrahman. (2008). Pengembangan Model Materi Ajar Muatan Lokal Bahasa Inggris di Sekolah Dasar Jawa Tengah Yang Berwawasan Sosiocultural. Semarang: Universitas Negeri Semarang.

Geertz, C. (1973). The Interpretation of Culture. New York : Basic.

Iswanto, S. (2015). Pengembangan Bahan Ajar Sejarah Lokal Berbasis Nilai-nilai Sulam Kerawang Gayo untuk Meningkatkan Karakter Bangsa KelasXI SMA Negeri di Kabupaten Bener Meriah. Surakarta: UNS.

Janit, A., Hammock, G., \& Richardson, D. (2011). The Power of Fiction: Reading Stories in Abnormal Psychology. International Journal for the Scholarship of Teaching and Learning, 5 (1): 1-14.

Kidd, D. C \& Castano, E. (2013). Reading Literary Fiction Improves Theory of Mind. Science, 135: 377380 .

Mua'rifah, Alif. Menghidupkan Kembali Budaya Lokal untuk Membangun Karakter. Diperoleh 2 November 2017 di http://uad.ac.id.

Nomor 17 Tahun 2010 pasal 34.

Nunan, David. (1995). Design Task for Communicative Classroom. New York: Cambridge Languange Teaching Library.

Nurgiyantoro, B. (2013). Sastra Anak: Pengantar Pemahaman Dunia Anak. Yogyakarta: Gadjah Mada University Press.

Panjaitan, dkk. (2014). Korelasi Kebudayaan dan Pendidikan Membangun Pendidikan Berbasis Budaya Lokal. Jakarta: Pusat Obor Indonesia.

Renstra Kemendiknas 2010-2014. 
Soetomo. (2012). Keswadayaan Masyarakat, Manifestasi Kapasitas Masyarakat untuk Berkembang secara Mandiri. Yogyakarta: Pustaka Pelajar.

Suhartini. (2009). Kajian Kearifan Lokal Masyarakat dalam Pengelolaan Sumber Daya Alam dan Lingkungan. Yogyakarta: UNY.

Sularso. (2016). Revitalisasi Kearifan Lokal dalam Pendidikan Dasar. Jurnal Pendidikan Sekolah Dasar, Universitas Ahmad Dahlan Yogyakarta, 2(1): 73-78.

Susanti, R. D. (2015). Pembelajaran Apresiasi Sastra di Sekolah Dasar. Elementary, 3(1): 135-154.

Utari, U., Dedeng, N. S., \& Akbar, S. (2016). Pembelajaran tematik berbasis Kearifan Lokal Di Sekolah Dasar dalam Menghadapi Masyarakat Ekonomi Asean (MEA). Jurnal Teori dan Praktis Pembelajaran IPS, 1(1): 39-44.

Yaumi, M. (2012). Prinsip-prinsip Desain Pembelajaran. Jakarta: Kencana.

\section{Copyrights}

Copyright for this article is retained by the author(s), with first publication rights granted to the journal.

This is an open-access article distributed under the terms and conditions of the Creative Commons Attribution license (http://creativecommons.org/licenses/by/4.0/). 